\title{
CRIES AND WHISPERS: EXHUMING AND NARRATING DEFEAT \\ IN SPAIN TODAY
}

\author{
Francisco Ferrándiz \\ Spanish National Research Council (CSIC)
}

Post-print version. The final, definitive version of this paper has been published in the Journal of Spanish Cultural Studies 9(2): 177-192.

http://www.tandf.co.uk/journals/carfax/14636204.html

In this paper, I will reflect on the impact in contemporary Spain of the production, circulation and consumption of narratives and images of Civil War terror and suffering, specifically those resulting from the opening of mass graves from the Francoist repression. This sharing of narratives has to be seen in the context of a broader and highly controversial process of reconsideration of the Civil War as a traumatic past. At a time when Spanish society is engaged in important debates regarding the singularity or plurality of our identity and the structure of our territorial organization, these exhumations are bringing to light rather disturbing information regarding our past, our present, and probably our future as well. The excavation of these "crime scenes" in various parts of the country is provoking heated discussions and performances in family contexts, politics, historiography, the media, the arts, and the public sphere in general. For example, the public display of skeletons, skulls and bone fragments bearing the marks of violence from "perimortem" tortures to bullet wounds and coups de grâce - is bringing back tragic stories that, for many relatives but also for civil society at large, were for decades mostly silenced, told in whispers, imperfectly transmitted in limited family circles, or simply ignored. The screen of silence, fear and self-censorship has been particularly strong in local, rural contexts. Exhumation and narration are inextricably entwined. Exhumations elicit storytelling; conversely, their meaning and social impact depend on the available repertoire of competing "memory plots." These range from expert discourses, political initiatives, media reports, memoirs, and artworks to more local, fragmented, and "fugitive" memories 
(Steedly 119-143) that have barely survived in the interstices of the dictatorship's hegemonic accounts of "Victory," remaining largely ignored since the dictator's death.

\section{Exhuming in Contemporary Spain}

Exhumations are complex, troubling collective performances in cultural, political, and sociological terms. Mass graves can be understood as a sophisticated technology of terror production. Despite their large numbers, they need to be interpreted in their specific context - that of their production and that of their excavation. The deliberate piling together of unidentified corpses in unmarked graves, inscribing on them the perverse condition of "cuasi-disappearance," encourages disorder, anxiety and division in any given society (Robben 93-7). This kind of burial practice is designed to obfuscate the memory of violent repression and to consolidate regimes of fear that may last for decades. But as social and political circumstances evolve and the regimes founded on the production of mass graves disappear, the latter metamorphose from crude instruments of terror into uncomfortable evidence of barbarism with very relevant symbolic, social, political and sometimes judicial consequences. As the Spanish case shows, the disquiet provoked by the presence of mass graves, no matter how attenuated, can last for generations and trigger a flashpoint if appropriate circumstances arise. The consequences of a shift of public attention to such mass graves, whether exhumed or not, will vary according to the national and international contexts in which the remains are investigated, located, and managed (Verdery 3). In all cases, the exhumation of victims of mass killings is necessarily controversial and has profound repercussions on both the living and the dead. States may have total or partial involvement in the exhumation process; they may block it; the task may be taken on by default by non-state national or international organizations or grassroots movements. In turn, exhumed bodies have a complex social, political and cultural life (Verdery 3), and inevitably challenge the historical fate of the "rival" dead killed on the other side during the period of conflict. 
The current exhumations in Spain are not taking place in a vacuum. During the dictatorship, thousands of corpses lying in mass graves and killing fields, mostly those of "nationalists" killed by republicans, were unearthed, identified, relocated to more dignified burial sites, their names inscribed on plaques, and inserted into the commemorative cycles of the dominant Francoist discourse of "Victory." Although some of these corpses entered a broader narrative of collective martyrdom in local contexts, others made it to the national press, ${ }^{1}$ and a significant number were disinterred in order to be sent to the Valle de los Caídos, ${ }^{2}$ where Franco was to build a megalomaniac monument honoring his military victory and the memory of the "martyrs for God and Spain." Relatives of victims of the Francoist repression had also organized exhumations, particularly in the late 1970s and early 1980s in regions such as Navarre and La Rioja. Yet, Spain had to wait till the twenty-first century to see a systematic process of excavation, documentation, and dissemination of information about common graves containing the remains of the many people executed under Franco's rule. ${ }^{3}$

For decades, the hundreds of mass graves resulting from Franco's repressive policies mostly remained a "public secret." Whether deliberately ignored, alongside other aspects of the war, by intellectual and political elites since the mid 1950s and during the transition to democracy, in the name of reconciliation (Juliá, "Echar al olvido" 20), ${ }^{4}$ or retaining some of their terrorinducing aura locally, mass graves remained invisible time-bombs ticking beneath the surface of familiar landscapes, further covered over by new political pacts and amnesty laws. That these time-bombs were by no means deactivated is shown by the intense controversies and key political and symbolic capital invested in their location, excavation, and management in the last few years. Once they started to be systematically opened in the early 2000 s, the process took on momentum, with some pro-exhumation associations organizing more stable teams of experts, and technical protocols being developed to normalize the excavation process and identification procedures. 
Political leanings have played a major role in shaping debates on the appropriateness, legitimacy and significance of the exhumations. Generally, right-wing politicians accuse them - and the whole "memory recovery" process, including the recent "Law of Historical Memory" approved on October 31, 2007 of dynamiting the "spirit of the transition" by promoting a resurgence of the "two Spains" with a new brand of guerracivilismo. On the left, positions are no less contentious, including generational disagreement over the management of the "historical memory" of defeat and its main sites: battlegrounds, graves, monuments (Ferrándiz, "The Return" 11-12). In the context of these controversies - which have degenerated into slanging-matches on some TV and radio talk shows, and in parliamentary debates - exhumations have been crucial to a crude visualization of the mass killings, fuelling a broader debate regarding the scale and extent of the Francoist repression and its short- and long-term consequences. Thanks to the fast-track, high-visibility dissemination afforded by the new information and communication technologies, images of the disturbing massacres committed by Franco's troops and supporters started to spill over into public discourses and imaginaries, impacting on public opinion and particularly on the relatives - especially the grandchildren - of the defeated. For quite a few of them, the new image of their country as a landscape strewn with mass graves and untold stories has been unsettling, and many have become activists in local or national grassroots organizations or, at an individual level, have started to pay attention to their elders' war stories or to search for their buried relatives. While this groundswell continues in many locations across the country, stimulated by new institutional modes of financial and political support (Ferrándiz, "La memoria" 126-129, "The Return" 10), public interest has proved more spasmodic, as the originally shocking images of piled-up bodies and skeletons with marks of torture and bullet wounds are increasingly absorbed into a global pool of images of horror and violence. After the initial disbelief experienced by many, a steady process of normalization of the exhumations and their imagery is turning them into established performances - a predictable ingredient of the summer holiday news and investigative reports. Exhumations continue to be powerful memory 
triggers in local contexts, and more occasional animators of broader debates; nevertheless, one can anticipate that their nationwide impact (as expressed in media interest, for example) is likely to decrease, or that the media will increasingly treat them as one among many related initiatives, alongside institutional projects, museum exhibitions, academic conferences, documentaries, and a wide range of cultural productions, from theatre performances to novels to conceptual art.

The mass graves of defeat have in the last few years changed from emotional and political wastelands into emotionally charged minefields available for public exposure and debate. Most importantly, exhumations provide a bridge between the political production of terror and the intimate experiences of those defeated in the war. Broader, long-term analysis is needed to understand what kind of sociological, symbolic and political performance exhumations are becoming in contemporary Spain, and how long they can remain a hot spot for debates on the memory of the Civil War. Even if public attention shifts away from them, they will continue to be performed. Elsewhere I have emphasized the evertransformative, unstable quality of Civil War memory production and debate in contemporary Spain (Ferrándiz, "La memoria" 109-16, "The Return" 10-12), and the same can be said of exhumations as social, cultural and political performances of a ghastly public secret. The hugely sensitive horror stories they contain seem to assure them a decisive place in the "nervous system" (Taussig 1-10) of the Civil War, as a finite network of excitable synaptic terminals circulating from the hard data of the repression (torture evidence, malnutrition, bullet wounds) to highly charged personal objects and still unbound emotions.

\section{Narratives of Defeat}

Beside the ongoing work they perform in making available concrete data on the repression - particularly through forensic and archaeological reports, and still and moving images disseminated via the media or Internet - such exhumations provide an emerging context for the telling of narratives of defeat, on a scale unprecedented in Spain. Exhumations elicit many different types of discourses 
and public performances, ranging from on-site technical accounts by forensic scientists and archaeologists (later consolidated into scientific reports) to minimal but emotionally explosive gestures on the part of relatives and onlookers. In the complex, many-sided process of the 'recovery of historical memories' (I deliberately use the plural form), many different things of dissimilar intensity ranging from the public to the intimate - are being narrated at the same time, whether before, during or after the exhumation process. The excavation period is, logically, the most intense moment for the emergence, circulation and interaction of such narratives. In turn, these narratives often feed into the broader, currently booming cultural industry of Civil War memories, particularly if there is some kind of media impact.

The growing tangle of memory plots and discourses transmitting and reelaborating the "visions of the defeated" in the Civil War cannot be explored fully here (see Ferrándiz, "La memoria;" Ruiz Torres; Aguilar). I will focus on the memories that emerge during the actual exhumation process, especially those narrated by relatives of those being exhumed. Exhumations create a unique, short-lived environment where testimonies of repression and suffering, direct and indirect, are particularly valued and in high demand. The presence at the excavation of witnesses or relatives raises the expectation that they may reveal or confirm details about the events (the arrests, the moment of execution, the aftermath); share biographical information, photographs or other personal objects of those shot; contribute to the debates on the (contested) appropriateness of grave openings; or reflect on the now standard topics of the decades-long silence, fear and suffering. While not everyone feels like speaking up or reaching back to painful memories (and many refuse to do so), some of those directly affected by the past shootings and the present excavation of the crime scene may find in the exhumation a privileged public space for the telling of their stories - one that in many cases has been totally lacking to them previously.

Thus at most exhumations there is a potential pool of storytellers - whose informal measure of "authenticity" is largely proportionate to age and closeness to those whose bodies are being recovered - and usually also a sympathetic 
audience of "first-hand consumers" comprising other relatives, friends, onlookers, memory activists, journalists, plus various experts including forensic scientists, archaeologists, cultural anthropologists, or psychologists, in what can turn into a competitive scenario in terms of relationships and narratives. In turn, particularly if there is media interest, fragments of the stories being told can selectively spin off into the public sphere, to the extent that the Civil War "graveside testimony" has become a subgenre in national and international TV, radio, and press coverage. Atttendance at an exhumation is for most people - apart from certain professionals, journalists and activists - a once-in-a-lifetime experience. They are undoubtedly tense scenarios, progressively exposing, if only for a few hours, the brute evidence of cruelty and violence. The presence of the skulls and bones, the piled-up bodies, the marks of death and oftentimes mistreatment, colors the moods and testimonies throughout. Furthermore, exhumations take place in a sort of social limbo and symbolic vacuum. Apart from certain rules laid down by the organizers and the technical experts in charge - mostly for safety reasons and concerned chiefly with regulating access to the grave and organizing the testimony-recording process - there are no explicit guidelines governing the interaction of relatives with each other or with others present. Nor does the relatives' way of relating to the unidentified bones follow any clear pattern. No symbolic protocol can fully cover the exhumation's complexities. Rituals of introduction and mutual recognition, and tiny or more visible commemorative acts, are commonly improvized in such a way that the various social actors at the site develop roadmaps - political, symbolic, emotional - for navigating the exhumation process, modulating their involvement in keeping with their personal or professional interests. Against the ever-present backdrop of the uncovered bones, conversation (informal and more structured), the giving and receiving of testimonies, and the collective sharing of memories and participation in commemorative acts, are crucial performances constructing a particular network of symbolic channels and social relations.

Alongside the location of gravesites, the creation of commemorative landmarks and rituals, the compilation of lists of those murdered, the 
dissemination of information, and the act of exhumation itself, there has in the last few years been a rush to record the voices of witnesses of the killings and relatives of those killed. Reports on such on-site narratives at the earliest exhumations have generated a demand for further narratives, which are now resonating with other voices circulating in other formats, from the media to politics to art. For many of those involved in the "recovery of memory" effort, the gradual disappearance of the mostly untold, unrecorded and unclaimed (yet crucial) experiences of those defeated in the war or affected by the repression, as the members of the oldest generation of victims gradually die, impoverishes the quality of Spanish democracy today. Many relatives and activists claim that the absence or minimal relevance of these voices in public discourse more than thirty years after Franco's death points to the long-term success of his regime of fear and to the persistence, albeit in altered form, of a hegemonic narrative of the war which largely excludes the defeated. There has been a recent, telling polemic among historians over issues such as the nature of collective memory; the tensions between history and memory; and whether the wartime and postwar repression has been over- or under-analysed, over-remembered to the point of saturation or shamefully forgotten during the last years of the dictatorship and since the transition to democracy. Also at stake is the role of politicians, intellectuals and historians in the process (Espinosa; Juliá, "De nuestras memorias;" Ruiz Torres, "Los discursos" and "De perplejidades"). This polemic illustrates the divergent opinions that exist in contemporary Spain over the interpretation and contextualization of the different accounts and representations of Francoist despotism and its consequences - victims' narratives, historical texts, artistic recreations, media products - while also questioning and demarcating their respective spheres of influence. This last issue is a major one. For example, while tens of thousands of pages have been written by historians, it seems clear that their expert accounts have not resolved all the anxieties on the ground. Conversely, while local narratives work very well in local contexts and have a strong appeal in certain media products, some historians feel that 
memory narratives are not always or necessarily an adequate companion to historiography.

Regardless of this controversy, the collection of testimonies by witnesses and relatives has become one of the primary aims of the grassroots movement for the "recovery of historical memory." These narratives are presumed to have a double healing effect. At a personal level, they break with years of shame, humiliation, fear and forgetting. At a social level, they feed into public discourse producing a collective recognition of their authors' suffering, in a long overdue act of historical justice. Yet, for many, it is already too late. Most of those who experienced the war as adults, on both sides, are already dead.

\section{Corpses and Narratives in Villamayor de los Montes (Burgos)}

Drawing on over four years' fieldwork into the excavation of mass graves and their consequences, in what follows I will explore how these public performances are serving to unlock and elaborate memories of the defeated in the Civil War. Although similar excavations are taking place throughout the country, I will focus my analysis on testimonies collected during the exhumation of forty-six bodies at Villamayor de los Montes (Burgos) in July 2004, organized by the Asociación para la Recuperación de la Memoria Histórica $(\mathrm{ARMH}){ }^{5}$ The $\mathrm{ARMH}$ wanted to set up a testimony-recording process that was as systematic as possible. Drawing on the experience of former exhumations, it was decided to create a specific "interview space" a few meters away from the grave, to which only interviewers and potential interviewees had access. This marked a departure from earlier exhumations, where the testimony-taking had been less formal or there had been no one available to make recordings.

In Villamayor, Inez Bootsgezel - a Dutch historian - and myself were present throughout the excavation hours and beyond, in a sort of outdoors studio set with two video cameras and chairs (Figure 1). We also offered to carry out interviews in alternative locations if felt more appropriate (as happened on a number of occasions). The prospect of recounting personal histories in public in an unfamiliar and rather complex and emotionally stressful setting aggravated 


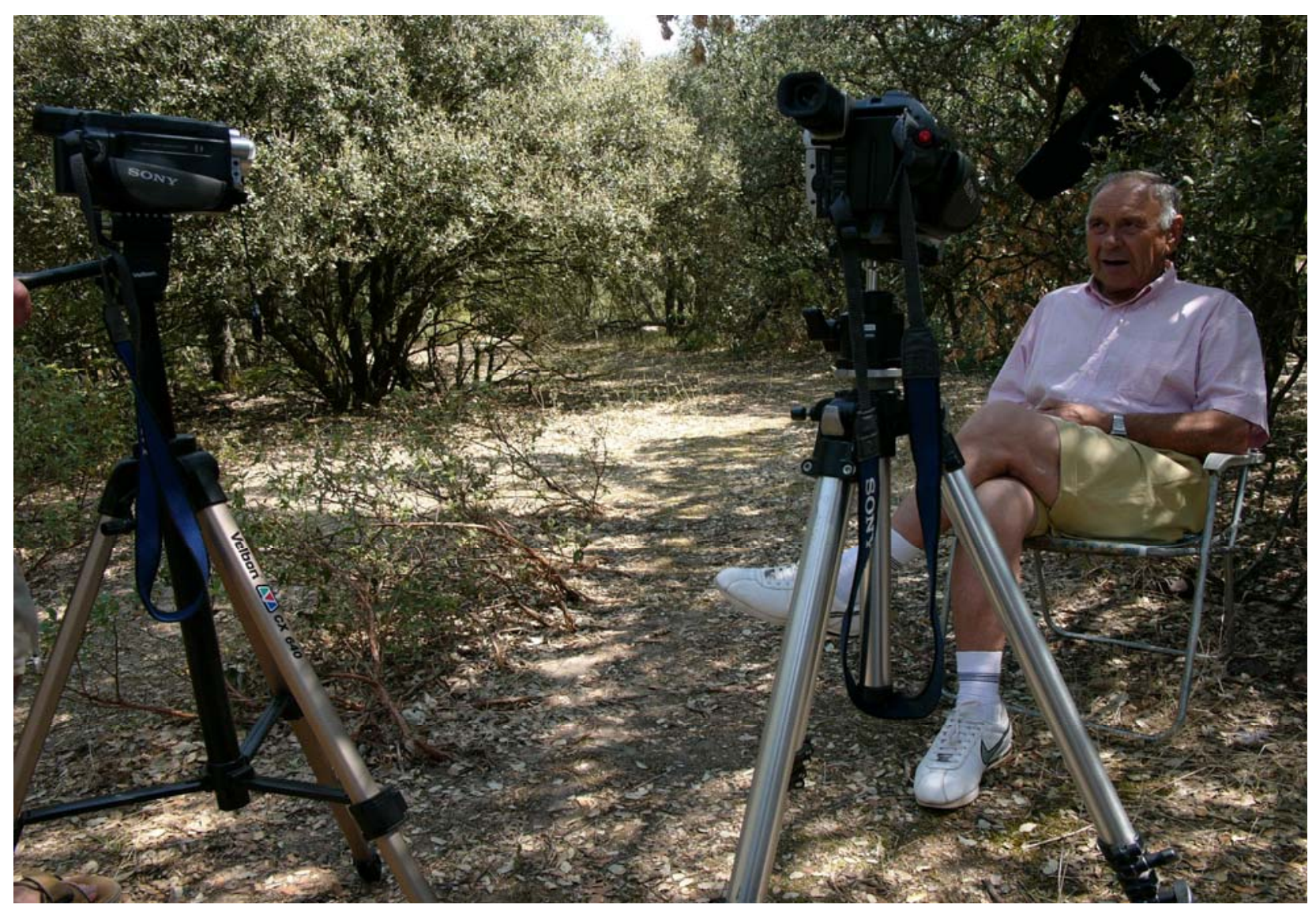

Fig 1: A testimony being recorded at Villamayor de los Montes. Picture by Clemente Bernad.

some people's hesitation and mistrust, while others were encouraged to speak by the presence of a concerned audience (other relatives and academic experts), and by the public legitimation enshrined in the act of exhumation and the emergence of an ad hoc - if shortlived - community of solidarity. Many people occupied in-between positions, modulating their stance in response to minute shifts in the interactive context, or switched from reluctance to willingness, or viceversa, as the exhumation progressed. In some cases, possible interviewees were brought to us by other members of the exhumation team: some of these went through with the interview, others did not. We ourselves talked to many people at the gravesite, and would suggest to some of them that they might offer their testimony. As the days passed and our presence and function became better known, many people started to volunteer of their own accord, wanting their voices and stories to be recorded. At certain points when there were large 
numbers gathered round the gravesite, we could barely handle the lines of people waiting to be interviewed.

The following vignettes provide a sample of the range of testimonies video-recorded at Villamayor, which is similar to that found at most exhumations I have attended. Although this essay does not allow for extensive quotation or indepth analysis, I hope that overall the sample offers an insight into the different ways in which such public performances relate to historically produced configurations of fear and oblivion, and to the lack of adequate forms of linguistic expression and public spaces for the articulation of memories related to defeat ${ }^{6}$. While recognizing the inevitable limitations and caveats, the exhumation process provides an unprecedented, ephemeral, and legitimate - albeit tense and painful - space for storytelling which cannot be replicated in any other environment. Nevertheless, I wish to start with a family discussion that was made possible by the exhumation but could take place - concurrently - only in a domestic space. For some, particularly the very elderly, the vicinity of the bones and the presence of unknown listeners can be a deterrent.

This was the case with "Florines," the brother of Vicente Díez Villaverde, an inhabitant of Villamayor shot on September 13, 1936 at the age of 27, along with seven other villagers. At the time the interview took place, Vicente was still lying unidentified in the mass grave. Florines, then in his late $80 \mathrm{~s}$, had moved to Barcelona many years before and had come to spend some days in Villamayor with his son Dositeo, both of them unaware that the grave was being excavated. Two of his great-nephews, Jesús and Raúl Zamora, had been very active in organizing the exhumation. Jesús, a young cameraman working for Telemadrid, was himself shooting a documentary on the exhumation and the resulting social and political relations in the village ${ }^{7} \mathrm{He}$ was thus conducting a parallel track of interviews with inhabitants of Villamayor, and was often present at the exhumation with his professional photographic equipment. Almost every day, Florines would sit by the dig for hours on end, his eyes fixed on the emerging bones. Jesús had urged me to interview Florines, since he was a leading protagonist of the exhumation, of appropriate age and kinship. He suggested that 
we conduct the interview at his home, and not at the gravesite, where he would not speak. Neither did he speak much when we interviewed him in his patio, in a more relaxed and friendly atmosphere where I was the only unfamiliar person. His son, his two great-nephews and myself were only able to elicit very general statements about the killing and its consequences for the family. "Total que los que se llevaron no volvieron a aparecer más. ¿Y quién se metía a defender estas cosas? Nadie. No nos atrevíamos a rebullir, nadie se atrevía a resoplar a los que tenían mando en el pueblo." "Era por la envidia, las envidias por las fincas y la leche... y cada uno tenía sus escritos de las tierras y eso... pero, amigo, les dolía que podríamos comer... con las fincas esas... mil cosas como esas...." "Mi madre, la pobre, cuánto peleaba... amigo... no se pudo hacer nada...Todo el mundo nos hemos callado...." Regarding the exhumation, "nunca pensé que esto... que fuera a pasar nada de esto, pero amigo... todo llega, todo llega... Yo ya me había conformado, pero si la gente no se conforma, pues que hagan lo que Dios quiera.... La vida sigue...." Eventually, when asked about the identity of those taken away and killed that night, Florines appealed to his senility to stop the conversation going into more detail. "No me acuerdo ya, no me acuerdo de cómo se llamaban (los fusilados del pueblo), es lo que quiero decir yo.... Como uno trata de olvidar ciertas cosas, ya le digo, no me acuerdo. Además, yo he perdido mucha memoria. (...) Yo ya no respondo de nada, porque ya digo que he perdido la memoria... de tal manera que no sé dónde me encuentro, es cojonudo esto... con lo que me he defendido yo, pero, amigo... he llegado a una época que no sé dónde me encuentro... qué barbaridad...."

“¿Y a sus hijos les contó poco de todo esto?," I asked. "Poco," he replied. "Nada," added Jesús, who later described this story as a "top family secret." “ ¿Y para qué? ¿Para qué?" Florines added. At this point, the group interview with Florines changed gear into an unexpected family conversation that had never taken place before, when his son Dositeo, aged 54, suddenly said: "yo me estoy enterando ahora, de todo esto...." Until he got to Villamayor and was confronted with the exhumation, Dositeo vaguely knew that one of his uncles had been "taken away" during the war, but not that he had been murdered in this way. "iEs 
que yo ni sabía que tenía un tío que se llamaba Vicente! Tenía una parte de la historia de la familia obscurecida." He was even more surprised to learn from this conversation that, when he was killed, his uncle Vicente was married and had two children, a boy and a newborn girl. The baby, Casildita, died of "friura" (coldness) soon after the killings. "Yo he oído que si del susto que se llevó la madre, Victoria.... La madre... se revolvió entera, no pudo alimentarla, darle leche... algo así nos han dicho," Jesús added. Vicente's son (also called Jesús) had survived but had remained an ambiguous and "errant" 8 presence in the family, dying in middle age with serious personal and drink problems. "Oye, y a Jesús... ¿ ¿tú a Jesús con quién lo relacionabas?" asked Raúl. Dositeo replied, 'Pues no sabía de quién... primo carnal mío y no sabía de quién... Porque nunca me habían dicho, oye, es que esto, y esto y esto.... Era primo mío pero era como un primo... aparecido.... ¡A Ahora comprendo todo! Ahora comprendo todos los problemas." "Porque estaba encabronado, porque venía al pueblo y se encabronaba," said Jesús. Dositeo summed up his father's attitude like this: "Mi padre tiene ese miedo que tienen algunas personas mayores. Hay personas que tienen más sentimientos que otros, que han padecido más que otros, otros que no han querido olvidarlo nunca.... Hay otros que, por ejemplo mi padre, es de los que prefiere olvidarse de todo ello, y su olvido es desde el día en el que se lo dijeron hasta ahora...." The conversation was further animated by the appearance of a family album where some of the protagonists of the story were portrayed. Florines, who had remained largely silent during this second part of the conversation, looked at his wrist and muttered, "My watch just stopped." There was no image of Vicente in the family album. However, two pictures of him, including a snapshot with his young son Jesús on his knee (Fig 2) had been brought from Barcelona to the exhumation, where they were shared and discussed for the first time by the family at large, and made available for public consumption. 


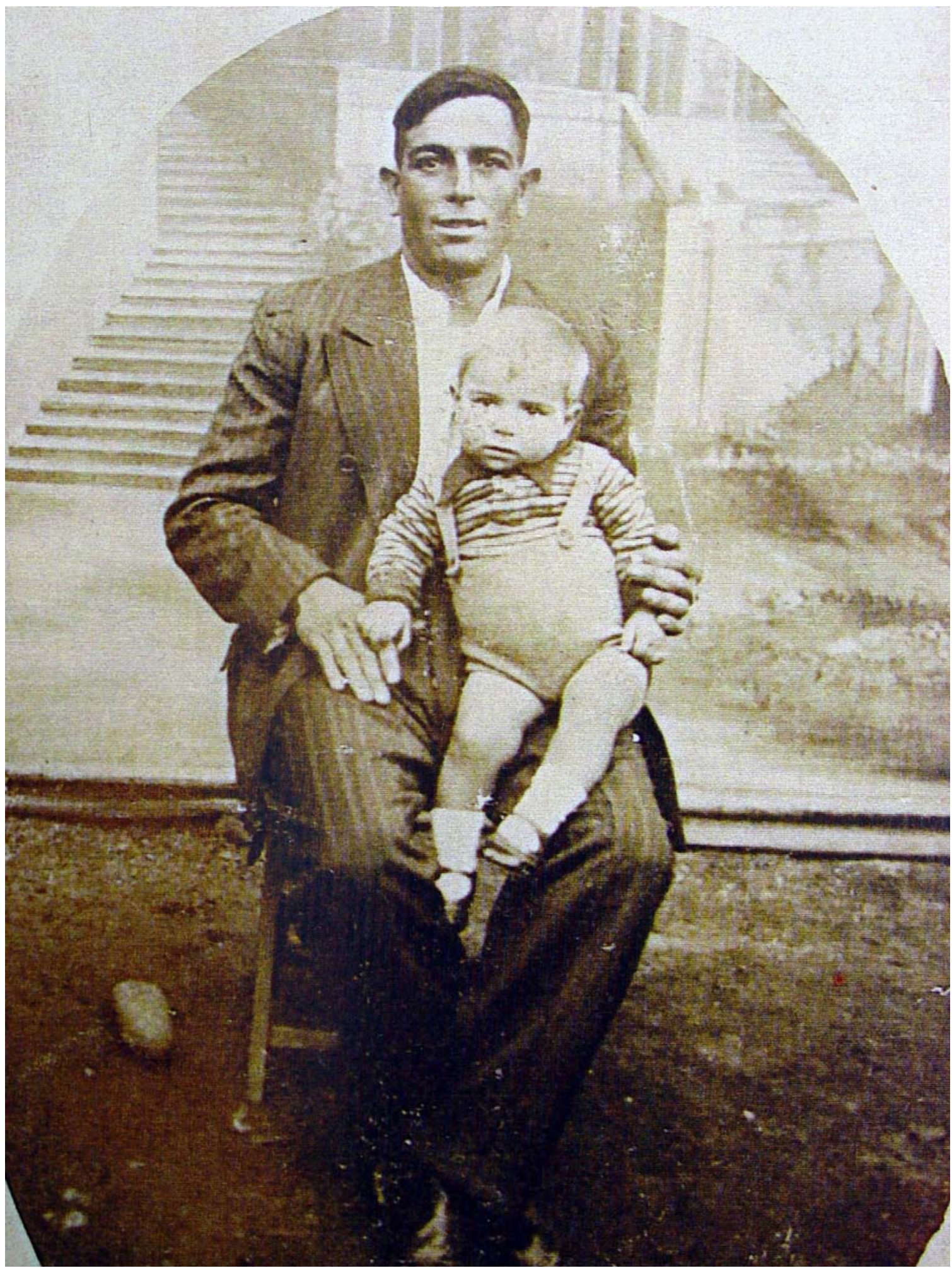

Fig 2: Vicente Díez, shot in Villamayor, and his son Jesús Díez. 
This example of a family where sensitive information had been shortcircuited for decades - whether out of fear, repugnance, a desire to protect the family, or a combination of these things - is not uncommon. In this case, the exhumation and the many stories and rumors circulating around it had triggered an urgent demand to know more on the part of the younger generation, eager for these revelations to be recorded in the context of the excavation as a public memory-performance. The decision to hold the interview in a family environment pre-empted possible disruption by unwanted listeners and allowed for a more private elaboration of previously disconnected or unknown information. The discomfort produced by the exhumation site, the ad hoc community of listeners and the recording apparatus could express itself in other ways, as for example in this second case. "Por favor, no me saques la cara en el vídeo," we were asked by Manuel Lorenzo, from the neighbouring village of Lerma, where many of those massacred at Villamayor came from. "¿Pero no le importa si le filmo las manos o los pies?" I responded. This was the second time that Manuel had come to us. During the night, he had realized that he was not satisfied with his first spontaneous words on camera the day before. To put things right, on this second occasion he read a more formal declaration he had written some days before when he learnt that the ARMH was working to locate the grave; he had printed it out for the occasion on a sheet of paper covered with deletions and corrections in the margins. On this occasion, he wanted the testimony to be recorded at the graveside, albeit with the relative anonymity afforded by the camera focusing on his feet (see Fig 3). The statement he read out, with a certain solemnity, was addressed to the $\mathrm{ARMH}$, thanking the organization for helping to recover his father's body: 


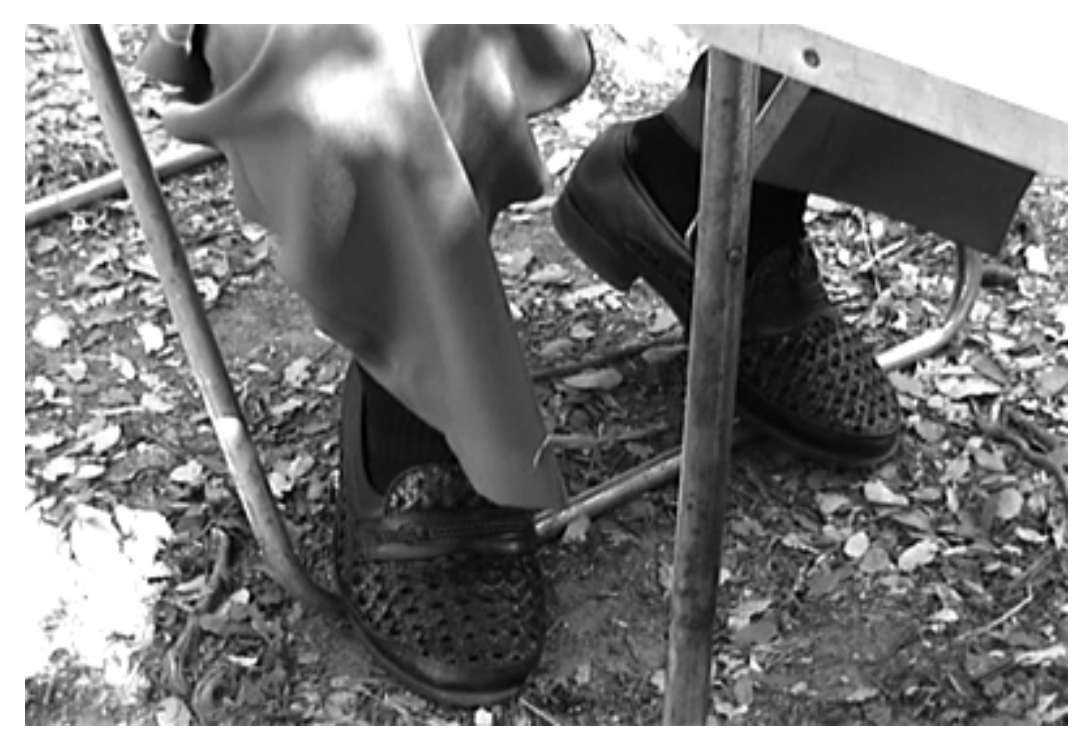

Fig 3: Manuel Lorenzo's feet as he records his testimony.

Acabo de cumplir setenta años, y casi toda mi vida ha estado marcada por la falta de mi padre y la forma ignominiosa y absurda con la que le quitaron la vida algunos desalmados. Hace unos días vi por televisión las excavaciones que se estaban realizando en la provincia de Burgos para exhumar los restos de personas asesinadas en el año 1936, y creo que puedo contarme entre las víctimas de aquella barbarie (...). Nací en Lerma en 1932, mis padres: Julián Lorenzo Aires y Claudia Martínez Manso; mis hermanos: Julián y Santiago. En 1942 nos internaron en colegios a los tres hermanos, y ya no volvimos a vivir en nuestro pueblo. Hemos visitado a mi madre ocasionalmente hasta que murió, en 1994. Por esta razón, tengo pocos datos de mi padre y de lo sucedido. Nadie, ni mi madre, quiso informarme de los motivos o circunstancias de su asesinato (...). Lo poco que sé es que era de La Fregeneda (Salamanca), hijo de Julián e Isabel, y parece ser que su condición de jornalero, después de trabajar en el Metro de Madrid, en su primera línea, le llevó hasta Lerma, participando en la construcción de la línea férrea MadridBurgos (...). Cuando comenzó la guerra, mi padre trabajaba en Consumos, estaba afiliado a la Casa del Pueblo (UGT), ${ }^{9}$ y parece ser que 
ese "delito" me privó de él (...). Durante más de sesenta años, nadie habló de esto en público. Parece que sólo interesaba el genocidio cometido en Argentina y Chile. Lo nuestro seguía ocultándose. ¿Gozarán de inmunidad toda la vida los culpables? Nuestras madres van muriendo sin ver que se hace justicia. ¿Moriremos también los hijos sin verla? (...) Desearía, con ayuda, o a través de la Asociación, hacer esta petición al Gobierno actual: que añada a su programa, cuando tantas reivindicaciones se están pidiendo, e incluso exigiendo, el esclarecimiento, exhumación, identificación y entierro cristiano de todas aquellas personas que fueron asesinadas ignominiosa y bárbaramente durante los años 1936-1939 y de las que, al cabo de casi setenta años, ninguna autoridad, ni judicial ni ejecutiva, de este país, en el que se llegó a decir que ya no existían dos Españas, ha prestado la menor atención a la barbarie cometida (...). Las escasas veces que ha habido oportunidad de exponer este tema, parece como si fuera infeccioso o candente, se rechaza y se mira para otro lado (...). Todo es silencio. Nadie se atreve a hablar. Es una auténtica conspiración. Las víctimas enmudecen (a los nueve años me internaron en un colegio y recuerdo que mi madre decía: "no digáis a nadie lo de vuestro padre").

Obviously, many of those giving testimony today were infants, children, or adolescents at the time of the killings. In the case of Manuel, who was four when his father was killed, he chose to articulate his public testimony starting with the present and then moving back to the past, in the form of a manifesto briefly outlining his story and the silence in his family, and asking directly for political action. Rules of telling and listening are negotiated on the spot. In this case, the combination of relative anonymity (no face on videotape) and a formal statement created for him the adequate distance to come out of the closet more comfortably.

In other cases, the narrative is mainly taken up with distant memories of childhood, focussing and coloring the testimonies and the listening context. 
Children's imaginations, within their specific cultural and historical context, are a toolbox full of powerful metaphors that act as vehicles for early experiences of fear and suffering. One important challenge for research in the Spanish case, in a comparative perspective, is precisely the collection and interpretation of such childhood memories evoked decades later. Carmen Pérez, aged 78 at the time of the Villamayor exhumation, was still unsure whether her father and uncle were lying in that grave or in some other in the region. But the succession of exhumations in the area had already unlocked the past for her, convinced that, sooner or later, her father would be found and that all the bodies in the graves around Lerma, Villamayor and Aranda de Duero were the result of the same repressive operation.

Yo tendría 8 o 9 años. Me dijo mi madre que mi padre estaba segando, y fue mi abuelo a llamarle... y luego bajó mi abuelo a caballo a Lerma para ver para lo que lo querían... y eché yo a correr detrás de él hasta el cementerio, y allí me cogieron y me devolvieron para casa.... ¿Y sabes lo que me pasó? Que me quedé negra, como... el hollín, me dio como un "paralís" y estuve paralizada un año, del susto.... Estaba como una cosa muerta, como que oía cosas, me puse negra... debe ser de la sangre congestionada... me tumbaba en la cama y no sabía ni lo que hacía, después mi madre como tenía que ir al campo a segar, y me dejaba en el salegar, allí quieta, hasta que venía, sentada en una silla, pero negra, eso me pasó a mí cuando 'aquello'.... Un curandero me curó, me daba la botica, tenía que ser con cuchara de madera o cuchara de cristal, para darme el medicamento, no sé lo que me daría aquel señor... yo las pasé muy mal.... Fue del susto que me llevé, al ver que todos se echaban a llorar, quede sobrecogida.... Desde el día que vino mi hermano y me dijo que estaban mirando aquí, tengo una cosa, una cosa, una cosa... vaya si es triste... entonces estaba yo como una princesa, y desde entonces tuve que estar como una pordiosera, nada más que eso.... 
That Carmen absorbed the mourning and paralysis of wartime loss in her childhood body-memory brings us to a crucial dimension of defeat; namely, its somatic traces and expression in surviving relatives. Whether one calls it depression, grief, an inability to understand what was going on, or "sangre congestionada," Carmen was "sobrecogida" by the killings, and the family's reaction to the orphaned girl's dramatic symptoms, including her treatment by the curandero, can be interpreted as a form of furtive mourning in a family context.

If the testimonies of Florines, Manuel and Carmen are broadly accepted as accurate eye-witness memories of the effects of Franco's repressive policies, even if they were children, younger relatives of those being exhumed oftentimes consider themselves unable to tell their families' stories because they belong to the "wrong" generation. Susana Saiz came to the exhumation with her mother, Esperanza Asturias. She owned a flower-stand in Lerma and during our conversation revealed that she was an amateur painter. Three of her greatuncles had been killed by the nationalists, and two of them, Gregorio and Adolfo Nebreda Calvo, were believed to be in the grave at Villamayor. As the interview started, her mother sat down in the interview chair while she remained standing beside it, punctuating her mother's narrative. The strongest presence in our conversation was Esperanza's late mother, the most conspicuous absent witness in the family. A recurrent image coming to their minds during our conversation was that of her dressed in black, crying in silence in an armchair. Susana spent most of the time talking about her grandmother, trying to ascertain what her reaction might have been. "Ella tenía un carácter muy austero, siempre llevaba negro, y eso... estaba muy marcado por todo esto. La manera de ser, la manera de pensar, unas lágrimas y no saber por qué lloraba...." A bout of illness broke her sad restraint for a few hours. "Sería a los 80 años, una vez que estuvo en el hospital y le dio una trombosis, y empezó a hablar.... Era como que había estado frustrada durante un montón de años.... Echó al cura de la habitación, y a partir de ahí empezó a contar y mezclaba cosas, lo cotidiano con lo otro, y no se la entendía bien... pero estaba hablando de todo esto.... Como un delirio, pero con realidades." She was sure that her grandmother would be pleased that 
the exhumation was taking place. Susana herself was very much in favor: "Yo quiero que esto salga a la luz. Taparlo no es una manera de superarlo. Abrirlo es una manera de hablarlo, de entenderlo, así es cómo se supera la historia (....) A veces pienso, si estaría mi abuela viva, ¿qué pensaría de esto? Y yo estoy segura de que estaría orgullosa de que los estarían sacando." The tragic events in 1936 had also marked her generation: "Yo y mis hemanos, somos todos así, tenemos algo rebelde, creo que está conectado con esta tragedia (...). Yo he sido rebelde con mi manera de actuar. Soy rebelde pintando (...). Mi pintura es mi libertad, no me la toca nadie. Seguramente algún día se haga la conexión, esto te marca, es imposible que no salga en mi pintura." Some time later, Susana overcame her misgivings about having an autonomous "voice" at the exhumation through an act of artistic and generational ventriloquism: she painted a picture of the excavation through the eyes of her dead grandmother. She phoned me so I could photograph it. In the painting, her grandmother's arm pulls back the black veil she used to wear to reveal the open grave, the skeletons and skulls showing bullet holes from the coup de grâce, with streams of tears flowing in both private and public spaces of mourning (see Fig 4).

In contemporary Spain, there is an emergent political culture with a grassroots base and a dominant generational profile (that of the third generation) eager to provoke, consume and recycle these largely "unclaimed" (Caruth 1-9) memories of defeat. Not as objective statements about the past but as complex, multifaceted, uneven and fragmented memory threads, which necessarily have to be interpreted from the vantage-point of the present in which they are told and heard, in the broader context of an information society with short attention spans and abundant opportunities and means for the spectacularization of suffering. Not as alibis for modernized forms of victimhood, ${ }^{10}$ but as necessary foundations of a healthier democratic system capable of assimilating local discourses, metaphors and images of defeat into a wider pool of inevitably controversial versions of the war, ranging from the more intuitive to the scientific. 


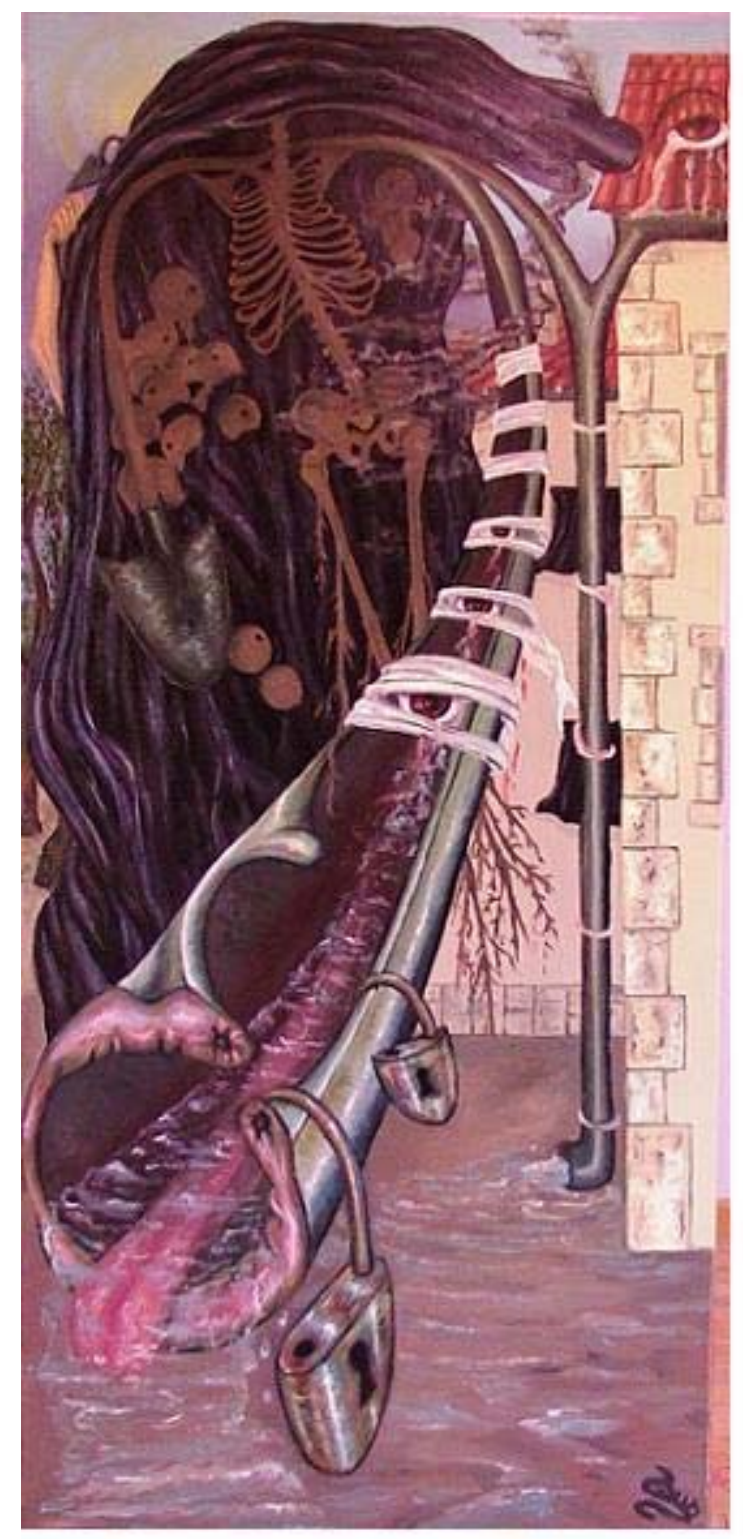

Fig 4: Susana Saiz's painting of Vilamayor's exhumation

Pro-Franco revisionist versions of the Civil War sell well in Spain. In the last few years, much research has been published by professional historians on the war and on the nature and range of repression on both sides. Politicians have had every opportunity to make their points known to the broad public in the debates surrounding the so-called "Law of Historical Memory" recently passed in parliament. A "memory industry" is producing a flood of plays, movies, 
biographies, investigative journalism and documentaries, some of which make a point of incorporating testimonies into their fabric. This essay has been concerned with asymmetrical memory discourses of a peculiar kind, told by people who are not usually in a position to have more than local or even family influence, and who oftentimes do not feel fully represented by the other, more articulate discourses on the Civil War widely available in Spanish society, whether political, cultural or scientific. These asymmetrical memory discourses are largely "narratives of defeat" initially told at or near the site of repression, in localities where such narratives have previously received scant public attention and have been denied legitimate spaces of articulation. They are expressed in local idioms of memory and distress, draw on childhood recollections, or, as in the case of Manuel, recycle more formal discursive forms to access their experience. They are multiple and fragmented, although tied to similar events. In many cases, they lack established plots and expressive cultures, and resort to symbolic fusions to generate commemorative acts. They are not just about cruelty and senseless violence in civilian spaces, but also about decades of public humiliation, injustice, destitution, everyday silence. What these narratives prove is that not all spaces of, and needs for, storytelling about the war and its aftermath have been exhausted in contemporary Spain. I have presented here a selection of the various types of narrative which are being told in the context of exhumations, and which are becoming relevant social, symbolic and political artefacts in contemporary Spain. As Aguilar has recently stated, democratic maturity can prove itself by absorbing complicated debates on the possible politics of memory, assuming their plurality, and accommodating demands that have significant, if not mass, social support (68). For their part, the refashioned narratives of defeat emerging around exhumations and other spaces of memory and commemoration seem to be negating their presumed fate as disposable "leftovers" of the transition period, claiming a more central place in the debates on the politics of memory in Spain today.

I should like to end with a brief quotation from Zacarias Díez from Villamayor: the grandson of Zacarías Diéz Ontañón, killed in September 1936 at 
the age of 57 , and one of the most astonishing storytellers I have met - a true compiler and distributor of the dispersed narratives told at the 2004 exhumation in his village. After all the bodies were finally retrieved, there was a ceremony where relatives took over the former mass grave and improvized a ritual in memory of those killed, including songs, poems, prayers, more formal speeches, offerings of flowers, and... more storytelling. Afterwards, the research team gave Zacarías a small ARMH poster that had been displayed at the entrance to the exhumation, with an extract from the famous poem by Miguel Hernández, "Elegía a Ramón Sijé." Throughout the excavation process Zacarías had recited the poem aloud, as a narrative peg on which to hang the stories of his family, and as the best expressive register available to him to describe the act of exhumation. When we were all about to leave, he concluded, holding the poster in his hand:

...besar tu noble calavera... para desamordazarte, y regresarte... que vuelvas otra vez a mí, eso es la palabra regresar, es volver.... ¿La he acertado? Quiero escarbar la tierra con los dientes... es que esto es exagerado... escarbar la tierra porque escarbar nada más escarban las gallinas, y las aves, quiero apartar la tierra parte a parte... a dentelladas.... Esto es una paradoja... secas y calientes... quiero minar la tierra hasta encontrarte.... Minar, justamente son las lombrices, las que minan la tierra, y los mineros, lógicamente.... Y besarte la noble calavera.... Esto es el sentimiento más noble al ser que nunca has visto, al ser más querido... y desamordazarte.... O sea, quitar el silencio, que otros tipos le taparon la boca para que no hablara... y regresarte.... Y volver a mí, que mío eras (...).

\section{Notes}

${ }^{1}$ See $A B C$, Arriba or Alcázar, which after the end of the war ran frequent reports on the exhumation, identification and reburial of "martyrs," single or en masse (for example, on February 25, $1940 A B C$ covered the exhumation of 1,500 "patriots" in Barcelona's 
Moncada cemetery), alongside public funerals, masses and the erection of monuments and commemorative plaques.

2 Julián Casanova has recently expressed astonishment at the secrecy still surrounding the number and origin of the bodies brought to the Valle de los Caídos, mainly in 1958 and 1959, from different mass graves in Madrid's Carabanchel and Almudena cemeteries and other cemeteries in the provinces, including bodies of executed republicans. Although Daniel Sueiro calculates that at least 20,000 bodies were there by early 1959 , the number may total 70,000 .

${ }^{3}$ Debates on the number of victims in the Civil War, military and civilian, are still an open issue and much research remains to be done. An appendix to Juliá's collective volume Víctimas de la guerra civil estimates the number of victims of Republican repression at around 50,000, and the figures for the victims of Francoist reprisals during and after the war as likely to total 150,000, at least half of which were not recorded in civil registers.

${ }^{4}$ In this article, Juliá distinguishes between "caer en el olvido" (a passive process) and "echar al olvido" (an active process of willfully ignoring something, felt to be necessary precisely because it is remembered all too well).

${ }^{5}$ See the photo essay by Francesc Torres in this volume, documenting the same exhumation.

${ }^{6}$ Although these narratives obviousy lend themselves to rhetorical, psychoanalytical, or discourse analysis, these interpretations are beyond the scope of this article.

${ }^{7}$ Olvidados (2004).

8 Jesús Zamora used this expression in a phone conversation on January 18, 2008.

${ }^{9}$ Unión General de los Trabajadores (Socialist Trade Union).

10 This point relates to a bigger argument that cannot be developed in this paper, although it is part of my research project. The evolving categories of victimhood regarding the Civil War resonate with new globalized discourses of victimhood and an updated transnational "mystique" of the Spanish Civil War. They are also being constructed (and can only be fully understood) in the context of a broader and highly partisan politics of victimization in contemporary Spain, including most particularly those affected directly by ETA terrorism and the March 11, 2004 train bombings. 


\section{Works Cited}

Aguilar, Paloma. "Los debates sobre la memoria histórica." Claves de Razón Práctica 172 (2007): 64-8.

Caruth Cathy. Unclaimed Experience: Trauma, Narrative and History. Baltimore: The Johns Hopkins UP, 1996.

Casanova, Julián. "El Valle de Franco." El País (2/11/07): 33.

Espinosa, Francisco. "De saturaciones y olvidos: Reflexiones en torno a un pasado que no puede pasar." Generaciones y memoria de la represión franquista: Un balance de los movimientos por la memoria. Ed. Sergio Gálvez. Special issue of Revista de Historia Contemporánea Hispania Nova 6/7 (2006-07). http://hispanianova.rediris.es/

Ferrándiz, Francisco "The Return of Civil War Ghosts: The Ethnography of Exhumations in Contemporary Spain." Anthropology Today 22-3 (2006): 7-12.

-.. "La memoria de los vencidos de la guerra civil: El impacto de las exhumaciones de fosas en la España contemporánea." Las políticas de la memoria en los sistemas democráticos: Poder, política y mercado. Ed. José María Valcuende and Susana Narotzky. Sevilla: ASANA, 2005. 109-32.

Juliá, Santos. "Echar al olvido: Memoria y amnistía en la transición." Claves de Razón Práctica 129 (2003): 14-24.

—. "De nuestras memorias y nuestras miserias." Generaciones y memoria de la represión franquista: Un balance de los movimientos por la memoria. Ed. Sergio Gálvez. Special issue of Revista de Historia Contemporánea Hispania Nova 6/7 (2006-2007). http://hispanianova.rediris.es/

— (ed.), Víctimas de la guerra civil. Madrid: Temas de Hoy, 1999.

Robben, Antonius C.G.M. "State Terror in the Netherworld: Dissapearance and Reburial in Argentina." Death Squad: The Anthropology of State Terror. Ed. J.A. Sluka. Philadelphia: University of Pennsylvania Press, 2000. 91-113.

Ruiz Torres, Pedro. "Los discursos de la memoria histórica en España." Generaciones y memoria de la represión franquista: Un balance de los movimientos por la memoria. Ed. Sergio Gálvez. Special issue of Revista de 
Historia Contemporánea Hispania Nova 6/7 (2006-2007). http://hispanianova.rediris.es/

—, "De perplejidades y confusiones a propósito de nuestra memoria." Generaciones y memoria de la represión franquista: Un balance de los movimientos por la memoria. Ed. Sergio Gálvez. Special issue of Revista de Historia Contemporánea Hispania Nova 6/7 (2006-2007). $<$ http://hispanianova.rediris.es>

Steedly, Mary. Hanging Without a Rope: Narrative Experience in Colonial and Postcolonial Karoland. Princeton: Princeton University Press, 1993.

Sueiro, Daniel. El Valle de los Caídos: Los secretos de la cripta franquista. Madrid: La Esfera de los Libros, 2006. (Originally published 1976.)

Taussig, Michael. The Nervous System. New York: Routledge, 1992.

Verdery, Katherine. The Political Lives of Dead Bodies. New York: Columbia University Press, 1999. 